\title{
Three new species of Nymphaea (Nymphaeaceae) in Australia
}

\author{
Surrey W.L. Jacobs ${ }^{1}$ and C. Barre Hellquist ${ }^{2}$ \\ ${ }^{1}$ National Herbarium, Royal Botanic Gardens, Sydney, NSW, 2000, Australia \\ Author for correspondence: surrey.jacobs@rbgsyd.nsw.gov.au \\ ${ }^{2}$ Department of Biology, Massachusetts College of Liberal Arts, North Adams, \\ MA 01247-4100, USA.
}

\begin{abstract}
Nymphaea alexii (aff. N. hastifolia, subgenus 'Confluentes'), N. carpentariae and N. georginae (both aff. N. macrosperma, subgenus Anecphya) are described from the Gulf Savannah region of Queensland and immediately to the south. A key is provided for the native and naturalised species of Nymphaea in Australia.
\end{abstract}

\section{Introduction}

As part of continuing studies in Nymphaea (Jacobs 1989, 1992, 1994), including sampling for an extensive DNA study, we have been able to collect good material sufficient to describe three new species.

Nymphaea alexii S.W.L.Jacobs \& Hellq. sp. nov.

$N$. hastifoliae similis sed staminibus cremiis, apice ovarii rubro, cristis seminis nonnunquam carunculatis differt.

Holotype. Queensland: c. $23 \mathrm{~km}$ N of Normanton, Karumba rd, $17^{\circ} 31.741^{\prime} \mathrm{S} 141^{\circ}$ 09.625’E, S. Jacobs 9325 \& C.B. Hellquist, 17 Apr 2005 (NSW). Isotypes: NASC, BRI.

Annual or perennial with a globose rhizome c. $2 \mathrm{~cm}$ diam. Blade elliptic, to $15 \mathrm{~cm}$ long, to $10 \mathrm{~cm}$ wide; margins slightly sinuate; stipules fused for $\mathrm{c} .1 \mathrm{~cm}$, the apical lobe free, acute c. $1 \mathrm{~cm}$ long. Flowers to $30 \mathrm{~cm}$ above the water, pleasantly-scented, dayflowering. Sepals 4-5, to $6 \mathrm{~cm}$ long, green outside; tip acute. Petals (18-)20-25(-40), to $5.5 \mathrm{~cm}$ long, $1.5 \mathrm{~cm}$ wide, lanceolate, white, grading into the stamens, no gap between petals and stamens; tip acute. Stamens cream, to c. 150; filaments membranous, to $17 \mathrm{~mm}$ long; anthers to $10 \mathrm{~mm}$ long; appendage white, much reduced and only visible on outer stamens. Ovary often red at the apex, with vestigial or obsolete sterile lobes; carpels 8 to 16 ; fruit globose, c. $4.5 \mathrm{~cm}$ diam. Seeds elongated, c. 1-2 mm long, glabrous, with longitudinal ridges, parts of the ridges sometimes proliferating irregularly into linear outgrowths when mature; cells of the testa with a comparatively large lumen (as judged from surface view) and short arms of more or less equal length, with a single 
margin (as opposed to the apparent double margin in N. hastifolia), ends of the arms of the epidermal cells neither expanded nor raised, the cell walls covered with regularlyarranged minute papillae (visible at c. 500X on a SEM).

Selection of specimens examined: Queensland: c. $23 \mathrm{~km}$ N of Normanton, Karumba rd, Jacobs 9325 a Hellquist, 17 Apr 2005 (NSW, NASC, BRI); c. 25 km S of Normanton, Croydon rd, Jacobs $9326 \&$ Hellquist, 17 Apr 2005 (NSW, NASC, BRI).

$N$. alexii grows in ephemeral billabongs and the shallow margins of more perennial lagoons (similar to N. hastifolia) during the end of the Wet and shortly after, and has often disappeared by May. It can be readily distinguished from $N$. hastifolia, or indeed from any other native Nymphaea sp., by its distinctive cream stamens and its small, ridged seeds. This species belongs in subgenus 'Confluentes'.

The species is named after Alex James Fussell, grandson of SWLJ.

A minutely papillose seed surface, has not been observed elsewhere in subg. Anecphya or 'Confluentes'. Interestingly, the seeds of this taxon are similar to those of Ondinea purpurea, as depicted by Schneider and Ford (1978), both in their longitudinal ridges and the granulate surface. A similar seed surface is known elsewhere in Nymphaea only in a group of species within subg. Hydrocallis.

Nymphaea carpentariae S.W.L.Jacobs \& Hellq. sp. nov.

N. macrospermae similis sed floribus albidis plerumque grandioribus, seminibus minoribus differt.

Holotype. Queensland: Burketown, bore drain of town bore, $17^{\circ} 44.879^{\prime} \mathrm{S} 139^{\circ} 32.899^{\prime} \mathrm{E}$, S. Jacobs 9329 \& C.B. Hellquist, 18 Apr 2005 (NSW). Isotypes: NASC, BRI.

Perennial with a globular to elongate rhizome to c. $4 \mathrm{~cm}$ long. Blade orbicular to elliptic, to $45 \mathrm{~cm}$ diam.; margins with regularly-spaced triangular teeth to $1.5 \mathrm{~mm}$ long; stipules fused for (1-)4-8 cm, terminal lobe free, acute, $0.5-1 \mathrm{~cm}$ long. Flowers to $40 \mathrm{~cm}$ above the water, lightly scented; day-flowering. Sepals 4 , to $6.5 \mathrm{~cm}$ long, green outside with purple streaks, streaks occasionally obscuring the green; tip obtuse. Petals mostly 12-22, 4-6 cm long, 1.5-2.5 cm wide, oblanceolate to spathulate, mostly white, rarely with some blue, with a space of c. $1 \mathrm{~cm}$ between petals and stamens; tip obtuse; when blue, most of the petals coloured, not just the outer petals and fading only slightly with maturity. Stamens yellow, mostly 150-300; filaments membranous to cylindrical, to $25 \mathrm{~mm}$ long; anthers $2.5-5 \mathrm{~mm}$ long, appendages vestigial or obsolete. Ovary lobes vestigial or obsolete; carpels 7-19; fruit globose, c. $4 \mathrm{~cm}$ diam. Seeds spherical to elongate-spherical, 2-3.5 mm long, c. $2 \mathrm{~mm}$ wide, with more or less continuous rows of short hairs usually c. $0.1-0.15 \mathrm{~mm}$ long; cells of the testa with a lumen of variable width and arms of unequal length with the ends of the arms expanded but not raised.

Selection of specimens examined: Queensland: Between Normanton and Maggieville, Clarkson 2697, 6 Nov 1979 (NSW681541); c. 4 km N of Normanton, Karumba rd, Jacobs 9324 \& Hellquist, 17 Apr 2005 (NSW);Boogan Lagoon, Jacobs 1280, 26 Apr 1974 (NSW681369); Forked Lagoon 'Wernadinga', Jacobs1368, 30 Apr 1974 (NSW681 368); E of Croydon, Georgetown rd, Jacobs 8588 \& Les, 22 Oct 1999 (NSW440424); Cumberland Chimney, c. 22 km W of Croydon, Georgetown rd, Jacobs 9320 \& Hellquist, 16 Apr 2005 (NSW).

1. Formal description of the subgenus Confluentes is waiting on the publication of the treatment of this group in the Flora of Australia series. 

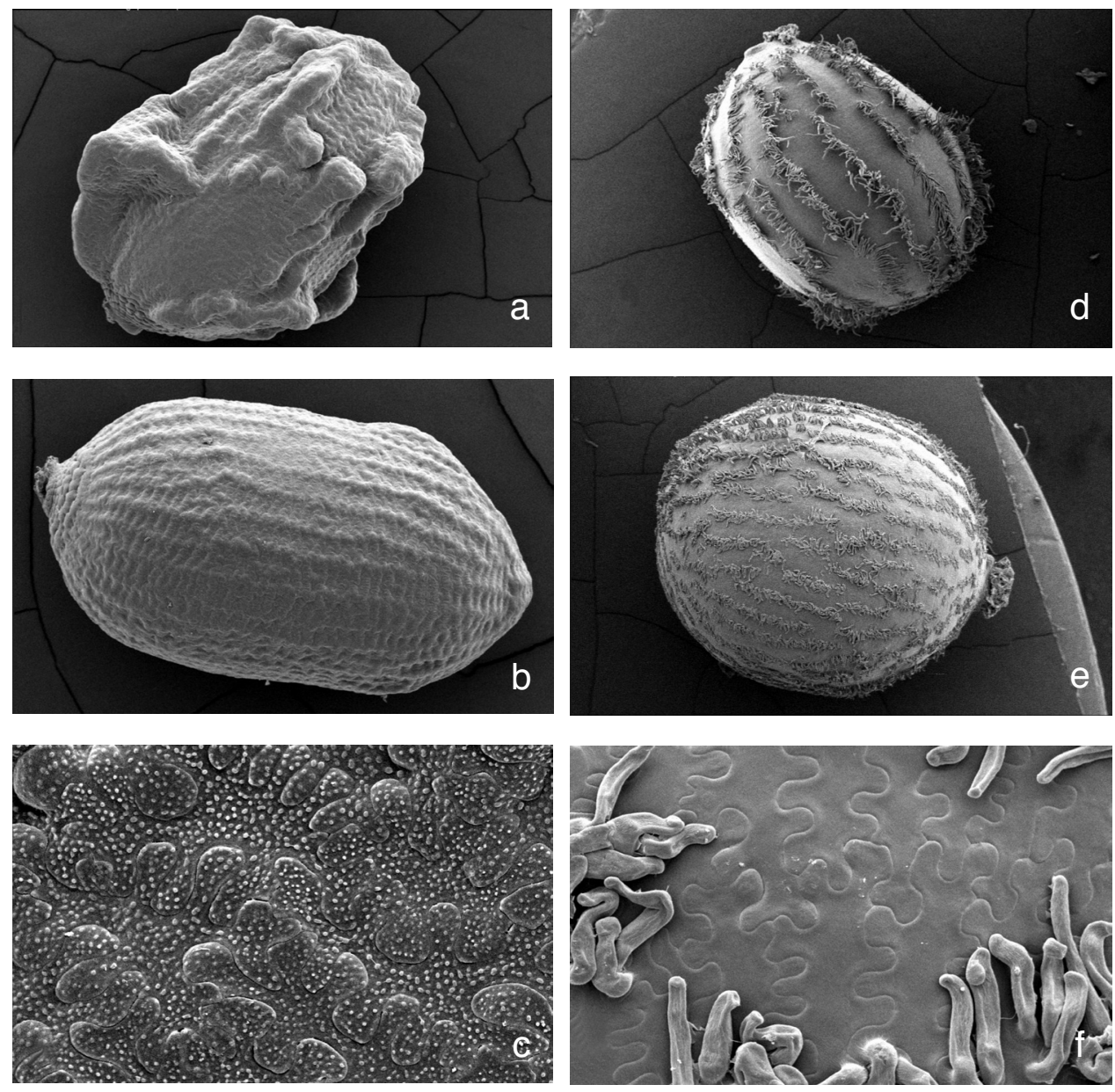

Fig. 1. Nymphaea seeds; the bare patches, or areas where the features are less well defined, are those areas where the seeds pack tightly next to each other. a, Nymphaea alexii (SJ9325) seed showing the ridges and the proliferation or caruncles present on most seeds (c. 35X); b, N. alexii (SJ9325) seed showing minimal proliferation, some proliferation is visible at top right; the ridges are clearly visible. This seed is from the same collection as Fig. 1a and all fruits examined have both types of seed (c. 35X); c, N. alexii (SJ9325) seed surface showing the characteristic papillae on the surface of the epidermal cells (c. 425X); d, N. carpentariae (SJ9329) whole seed showing the more or less continuous rows of hairs and a smaller seed than N. georginae in Fig. 1e (c. 25X); e, N. georginae (SJ9335) whole seed showing the partly disorganized and incomplete rows of hairs and a larger seed than N. carpentariae in Fig. 1d (c. 15X); f, N. georginae (SJ9335) seed surface showing the epidermal cells with a narrow lumen and short irregular arms (c. 225X) 
$N$. carpentariae grows in perennial or near perennial billabongs and lagoons around the Gulf of Carpentaria. It can be distinguished from N. macrosperma by the usually larger white flowers, and from $N$. georginae by the smaller seeds and by the blue-flowered forms of the latter fading with age. Although the differences in shape and dimensions of the seeds in N. carpentariae and N. georginae do not seem very great, when compared side by side the differences are quite striking. This species belongs in subgenus Anecphya. Specimens of this species have usually been included in N. immutabilis.

This is the original 'Albert De L'Estang' sent to Bailey in Brisbane; there are still some of the original distinctive seeds in the Herbarium (BRI). Most of what is now grown and sold as cv. 'Albert De L'Estang' appears to be N. immutabilis. The cultivar 'Andre Leu' is N. carpentariae.

The species is named for the Gulf of Carpentaria region in which it grows.

Nymphaea georginae S.W.L.Jacobs \& Hellq. sp. nov.

N. macrospermae similis sed floribus in quoque loco plerumque albidis caeruleisque, floribus caeruleis decolorantibus differt. A N. gigantea seminibus majoribus differt.

Holotype. Queensland: Georgina River, Camooweal, 19 55.576'S 138 06.903’E, S. Jacobs 9332 \& C.B. Hellquist, 19 Apr 2005 (NSW). Isotypes: NASC, BRI (blue-flowered specimen).

Perennial with a globular rhizome c. $4 \mathrm{~cm}$ diam. Blade orbicular to elliptic, to 60 $\mathrm{cm}$ diam.; margins with regularly-spaced narrow-triangular to triangular teeth to 2-4 mm long; stipules fused for $1-3 \mathrm{~cm}$ with free acute terminal lobes $0.3-1 \mathrm{~cm}$ long. Flowers to $30 \mathrm{~cm}$ above the water, fragrant, day-flowering Sepals 4, to $6.5 \mathrm{~cm}$ long, green outside with purple streaks, streaks occasionally obscuring the green; tip obtuse. Petals mostly 12-26, 4-7 cm long, 2-3.5 cm wide, oblanceolate to spathulate, white or, less commonly, blue, rarely pink, and fading with age, with a space of $\mathrm{c} .1 \mathrm{~cm}$ between petals and stamens; tip obtuse; when blue, most of the petals coloured, not just the outer petals. Stamens mostly 150-250; filaments membranous to cylindrical, to $25 \mathrm{~mm}$ long; anthers to $6 \mathrm{~mm}$ long, appendages vestigial or obsolete. Ovary often red with lobes vestigial or obsolete; carpels 7-19; fruit globose, c. $4 \mathrm{~cm}$ diam. Seeds globose to subglobose, (1.5-)2.5-4 mm diam., with often interrupted rows of short hairs c. $0.1-0.15 \mathrm{~mm}$ long; cells of the testa with a comparatively long-narrow lumen and arms of unequal length with ends slightly expanded but not raised.

Selection of specimens examined: Queensland: Georgina River, Camooweal, Jacobs 5531 \& P.Wilson, 4 May 1988 (NSW280651); Jacobs $9332 \&$ Hellquist, 19 Apr 2005 (NSW); Flood channel of Thomson River, Longreach, Jacobs $9335 \&$ Hellquist, 20 Apr 2005 (NSW).

N.T.: James River, nr 'Avon Downs', Chippendale s.n., 20 Jun 1960 (NSW); Jacobs 5300, 5303, 5304, 5306 \& K. Wilson, 7 Jun 2005 (NSW); Jacobs 9331 \& Hellquist, 20 Apr 2005 (NSW).

Nymphaea georginae grows in the billabongs and flood channels of the upper parts of northern rivers flowing into the Lake Eyre system. These waterbodies may hold water for $>1$ year but also are frequently dry for $>1$ year. It can be distinguished from $N$. carpentariae by the larger seeds and from $N$. macrosperma by the larger flowers of blue-flowered plants fading with age. This species belongs in subgenus Anecphya. This species has the strongest scent of any in subg. Anecphya, but it is still considerably less scented than species of subg. 'Confluentes'. Specimens of this species have usually been included in either N. gigantea or N. immutabilis. 
The species is named for the Georgina River, one of several in which it grows and the type locality.

\section{Key to native and naturalised species of Nymphaea in Australia.}

1. Petals yellow, grading into stamens (with filaments to $38 \mathrm{~mm}$ long); leaf blade margin sinuate; horizontal stolons and vertical rhizomes both present.

N. mexicana ${ }^{2}$

$1^{*}$ Petals white, blue or pink; grading into stamens or a distinct gap present; leaf blade margins various; stolons absent; rhizomes either horizontal, or vertical and more or less tuberous.

2. Rhizomes horizontal or suberect, elongated and vigorous; flowers more or less floating on the water surface. N. alba, N. odorata and hybrids

$2 *$ Rhizomes tuberous, erect; flowers standing clear of the water surface. 3

3. Petals grading into stamens; leaf blade with entire, sinuate or dentate margins. ............... 4

$3^{*}$ Distinct gap present between petals and stamens; blade with sinuate or dentate margin. .. 9

4. Filaments flattened, thickened, tough; leaf blade margin dentate; blade undersurface usually pubescent

N. pubescens

$4^{*}$ Filaments membranous and either cylindrical, or all flattened, or only some outer filaments flattened; leaf blade undersurface always glabrous; blade margin sinuate.

5. Anthers to $24.5 \mathrm{~mm}$ long; apical appendage to $10 \mathrm{~mm}$ long.

N. caerulea $^{3}$

$5^{\star}$ Anthers $13 \mathrm{~mm}$ long or less; apical appendage minute or absent.

6 Anthers cream; top of ovary frequently red; seeds with longitudinal ridges and these often with proliferations.

$6^{*}$ Anthers yellow; top of ovary rarely red; seeds without longitudinal ridges or proliferations.

7. Filaments to $25 \mathrm{~mm}$ long; sepals to $11.5 \mathrm{~cm}$ long; petals blue to mauve, white, or pink; widespread; habitats various.

N. violacea

7* Filaments to $18 \mathrm{~mm}$ long; sepals to $7 \mathrm{~cm}$ long; petals white.

8. Sepals usually with purple flecks, to $7 \mathrm{~cm}$ long; anthers to $8.5 \mathrm{~mm}$ long, sometimes apiculate; carpels 11-22; fruit to $2.5 \mathrm{~cm}$ diam.; seeds glabrous, $1.75-2.5 \mathrm{~mm}$ long, $1-1.5 \mathrm{~mm}$ wide, cells of testa without a 'double edge'; growing in more or less permanent water; Cape York Peninsula, New Guinea.

N. elleniae

$\mathbf{8}^{\star}$ Sepals without purple flecks, to $6 \mathrm{~cm}$ long; anthers to $5.5 \mathrm{~mm}$ long; appendage absent; carpels 8-16; fruit to $4.5 \mathrm{~cm}$ diam.; seeds glabrous, spherical, c. $1 \mathrm{~mm}$ diam., cells of testa with a 'double edge'; growing in ephemeral water on floodplains; N.T., W.A.

N. hastifolia

9. Filaments flattened and tough; petals usually $<10$; stamens usually $<25$; leaf blade margin sinuate; mature seed $<1.5 \mathrm{~mm}$ long.

N. nouchali

9* Filaments membranous, slightly flattened to cylindrical; petals usually $>10$; stamens usually $>50$; leaf blade margin toothed; mature seeds $>2.5 \mathrm{~mm}$ long.

10. Sepal margins pink; petals becoming dark pink with age; blade margin with sparse teeth to $2 \mathrm{~mm}$ long. N. atrans

$10^{\star}$ Sepal margins white or blue, rarely pink; petals not darkening with age, teeth usually more than $2 \mathrm{~mm}$ long.

2. The plant introduced in Australia is a hybrid involving this species, rather than pure N. mexicana, as in other places where this taxon is said to be introduced.

3. The introduced plant in eastern Australia is not typical of N. caerulea, originally described from Egypt, but better fits what has traditionally been treated as N. capensis. However, further work on the interpretation of the type of this latter name is required (J. Wiersema pers. comm.). 
11. Anthers to $6 \mathrm{~mm}$ long; sepals to $6.5 \mathrm{~cm}$ long; petals to 26 on fully developed flowers, white, deep blue, rarely pink; blade margin with teeth to $4 \mathrm{~mm}$ long.

$11^{\star}$ Anthers $>6 \mathrm{~mm}$ long; sepals to $12 \mathrm{~cm}$ long; petals to 34 on fully developed flowers, blue, white, or rarely pink; blade margin with teeth to $5 \mathrm{~mm}$ long. ............................................ 14

12. Flowers mostly blue, rarely pink or white, comparatively small; petals to $5 \mathrm{~cm}$ long and all the same colour; sepals to c. $4.5 \mathrm{~cm}$; leaves comparatively large with teeth on mature leaves cylindrical from a shallow triangular base; seeds globose to subglobose, $3-4.5 \mathrm{~mm}$ diam.

N. macrosperma

$12^{\star}$ Flowers mostly white with some blue, rarely pink, larger; petals to $7 \mathrm{~cm}$ long and all the same colour; sepals to $6.5 \mathrm{~cm}$; leaves not as large with teeth on mature leaves triangular to narrow-triangular; seeds globose to elongate-spherical, 2-4 $\mathrm{mm}$ diam. 13

13. Seeds spherical to elongate-spherical, $2-3.5 \mathrm{~mm}$ long, c. $2 \mathrm{~mm}$ wide, with more or less continuous rows of short hairs; flowers mostly white, rarely blue, no obvious fading with age.

N. carpentariae

$13^{\star}$ Seeds globose to subglobose, $2.5-4 \mathrm{~mm}$ diam., with often interrupted rows of short hairs; flowers mostly white but blue flowers still common, the blue flowers fading with age.

N. georginae

14. Anthers to $10 \mathrm{~mm}$ long; rarely apiculate; when coloured the petals fading with age; carpels 12-18; seeds ovate, pubescent, the hairs arranged in more or less continuous rows of short hairs; cells of the testa with a long lumen and short arms of equal length, the ends not raised, rarely expanded.

N. gigantea

$14^{\star}$ Anthers to $15 \mathrm{~mm}$ long; often apiculate; when coloured the petals usually not fading with age; carpels 9-20; seeds oblong, pubescent or rarely glabrous, with sparse to dense hairs in discontinuous or disorganised rows, sometimes almost appearing scattered; cells of the testa with a long lumen and arms of equal to unequal length, the ends sometimes slightly expanded but not raised.

N. immutabilis

\section{Acknowledgments}

We thank Andre Leu (Wonga Beach, Qld) for showing us cultivated specimens and sharing his locality information, Karen Wilson (NSW) for the Latin diagnoses, and John Wiersema (Beltsville, Maryland, USA) for continued discussion and encouragement.

\section{References}

Jacobs SWL (1989) Nymphaea in Australia. Water Garden Journal 5: 14-18.

Jacobs SWL (1992) New species, lectotypes and synonyms of Australasian Nymphaea (Nymphaeaceae). Telopea 4: 635-641.

Jacobs SWL (1994) Further notes on Nymphaea in Australasia. Telopea 5: 703-706.

Schneider (1978) and Ford EG (1978) Morphological studies of the Nymphaeaceae. X. The seed of Ondinea purpurea Den Hartog. Bulletin of the Torrey Botanical Club 105: 192-200. 